\title{
The Broadcast of the Candidates' Election Campaign for the 2018 Presidential Election on CRTV: Mediatization of Policy Discourse: Strategy, Forms and Figures
}

\author{
Ndibi Ola'A Fréderic \\ UYII, ESSTIC, Yaounde, Cameroon \\ Email:ndibif@yahoo.com
}

How to cite this paper: Fréderic, N. O. (2020). The Broadcast of the Candidates' Election Campaign for the 2018 Presidential Election on CRTV: Mediatization of Policy Discourse: Strategy, Forms and Figures. $A d-$ vances in Journalism and Communication, 8, 28-48.

https://doi.org/10.4236/ajc.2020.82003

Received: March 17, 2020

Accepted: May 25, 2020

Published: May 28, 2020

Copyright $\odot 2020$ by author(s) and Scientific Research Publishing Inc. This work is licensed under the Creative Commons Attribution International License (CC BY 4.0).

http://creativecommons.org/licenses/by/4.0/

\begin{abstract}
The specificity of media coverage of politicians and their supporters during election campaigns is to produce a speech for informative and persuasive purposes. We therefore assume that these policies have a discursive strategy to achieve their goals. To produce this effect on the receiver of information, the television medium uses a set of means that can be analysed on three levels: the media system, the thematics, and the rhetoric. This case study focuses on the outcomes of the official election campaign broadcast for the presidential election in the Republic of Cameroon and on the Cameroon Radio and Television (CRTV) - a national public service television station.
\end{abstract}

\section{Keywords}

Mediatization, Speeches, Politics, 2018 Presidential Election, Media Coverage, Politics Thematics, Rhetoric

\section{Introduction}

The Presidential Election is the major event in our young democracy. It is important that voters are able to form their opinion on the decisive choice before them freely and to the best of their ability. The role of the audio-visual media, which remains the main source of information for citizens on political life, is therefore decisive. There are areas devoted to this information, also known as election campaigns. It is necessary to distinguish between the campaign, in the broad sense, and the official campaign. The official campaign is short and its duration is fixed by the regulatory texts. It thus promotes electoral pluralism, and also 
ensures that the different parties and/or candidates can deliver their message and benefit from equal treatment, i.e. all candidates will have equal time to speak in the reserved space on the public audiovisual channel CRTV.

The reason and importance of the choice of our theme are measured against the yardstick of our young, fledgling democracy. Indeed, with this election campaign, we believe that Cameroon is entering more and more into the era of political marketing. Our objective is to evaluate how the most important candidates will try to fit their speeches in a technical mechanism, the one offered by television.

The media coverage of political speeches, omnipresent in all media throughout this election year, particularly on television, which has made it possible for us to follow one another, the reports of meetings, contradictory debates and the news magazines of sets, raises specific questions. First, because television and political parties are organizations, that is, institutions. In this respect, and because they both have the power to mediate, they make "choices in a possible arrangement of systems, programmes, themes, according to technical and social resources, according to the characteristics of the staff and the organisation, according to their relations with other media, according to the way they build the image of their audience" (Bourdon, 1998). Based on a significant organization of various materials (graphic, iconic, sound and linguistic campaign material), the two institutions construct a discursive staging of their discourse. Television statements are built on choices that lead to meaningful verbal and visual form. The media institution, in this case the CRTV, imposes rules that the candidate must respect, it does not dispense with any possibility on the scenographic and technical mechanism for example. From a constructivist perspective, political parties, for their part, participate through their audio-visual mediation in the construction of their vision of society, through a complex alchemy made up of the candidate's character traits, verbal statements for example.

How can we report on the media coverage of policies produced by television during the 2018 presidential election in Cameroon?

It is possible to sketch an answer by examining this question from three angles: that of the very mechanism of information; that of its theme; that of its rhetoric or its discursive staging. These three levels form the language of the media. To answer our question, our epistemological approach is empirical and based on the observation and analysis of television data. The analysis focus here is semio-pragmatic. This article therefore has three movements: it considers mediation only as a revelation of a certain number of mechanisms and processes whose analysis it outlines, it does not deal with all the media but only with information, itself limited to CRTV and also limited to a well-defined discursive space; finally, it examines how CRTV media and political parties organise their own rhetoric according to the image that is formed of their public.

\section{Research Method}

The objective of our study is to highlight the discursive strategies of policies produced by television. We will therefore try to analyse the forms given to polit- 
ical discourse by our media and to understand the status of the registration of candidates for election and their support, within these forms.

The presidential election for the presidential election of 07 October 2018 in Cameroon, the subject of our work, is the major milestone in our young democracy. It is important that voters should be able to freely and as far as possible form their opinion on the decisive choice before them. The role of the audio-visual media, which remains the main source of information for citizens on political life, is therefore crucial.

The election campaign therefore mobilized the media as a whole, and more specifically television. Television political broadcasts were in vogue. The channels gave the campaign an important place in their programmes, thus helping to enlighten citizens on the stakes of the election. Each channel, the effect of competition, presented its political programme, often on a daily basis. The viewer had never known such an abundance of political broadcasts before. By choosing the mediatization of policy speeches as a means of observing the construction of candidates' discursive strategies, we do not intend to report here on all the political programmes broadcast by Cameroonian television since the beginning of the campaign. Indeed, it is necessary to distinguish between the campaign, in the broad sense, and the official campaign. Some candidates have declared their intention to run long months before the election itself, sometimes by holding public meetings and intervening in the media. Needless to say, we will not cover this vast programme here: we will rely only on the period corresponding to the official campaign. It began on Saturday, September 22nd, and was interrupted in the evening of Saturday, October 6th, 2018, on the eve of polling day. This campaign is more closely monitored and is also much more limited in time. Indeed, in order to be elected, candidates must make their ideas and programmes known. Apart from meetings, door-to-door visits and market visits, the media are an essential means of communication. According to Order No. 020/MINCOM of 21 September 2018 on the conditions for the production, programming and broadcasting of election campaign programmes in the audio-visual media of the public communication service, for the election of the President of the Republic on 7 October 2018 and Order No. 021/MINCOM of 21 September 2018 establishing the order of precedence and airtime allocated in the public service audio-visual media for communication to candidates in the context of election campaign broadcasts, for the election of the President of the Republic on 07 October 2018, access to the audio-visual media of candidates for election falls within the special rules. These texts ensure in particular the possibility for the various parties and/or candidates to deliver their messages and to benefit from equal treatment on the public channel, CRTV. These rules include the allocation and determination of the speaking time allocated to candidates and the monitoring of equal treatment from which they should benefit.

As in any presidential election, each candidate has the right to present himself/herself on public television channels to address and enlighten the people in order to win their votes. He has a number of programmes of a fixed duration 
that it is free to organise as he wishes, such as meeting coverage, market campaigns or door-to-door campaigns; he also has the benefit of platform programmes where the media institution has partial control over its system. In the latter case, the responsibility for the programme is assumed by both institutions: the political party and the media.

In this reflection, we will therefore rely on the only official election campaign programme of the candidates for the presidential election of October 07, 2018 produced and broadcast from September 22 to October 06, 2018 by CRTV. This is therefore a rare form of television situation, where institutions, in this case the media institution CRTV, the candidate and his political party, are partly deprived of their power of media coverage. This television situation deserves to be carefully observed. If only because we are dealing with a programme that uniquely combines a familiar and repetitive mechanism (generic, pregeneric) with factual content that is renewed every day, all in full interaction with certain possibilities of expression specific to the medium and the candidate himself. In this situation, two types of mediation are combined to produce the message. If the media institution is required both to respect a set of specifications that is first imposed on it by regulatory texts (scenographic and technical mechanisms) in order to respect the principle of equality and balance, and by the specificity of the medium, conversely, each candidate must try to mediatize his or her own person, as well as his or her political programme through a programme whose programming is imposed on him or her. In other words, the acts of communication of political parties are fundamentally determined by the constraints of the situations in which they operate, and the television programme chosen is an almost imposed form. We assume that this candidate and his support have a language game and a discursive strategy: i.e. the particular use of a vocabulary to convey their ideas, or even a syntax, a style organizing the semantics of their speeches, rhetoric, visuals and inserts, all in relevance with the technical mechanism. This language game is the reference point for these speeches, to put it in Michel Foucault's vocabulary (Foucault, 1969). This candidate and his support must therefore try to include their language game in a technical mechanism, the one offered by television. The result is audio-visual discourse. These can be considered as the result of the constraints imposed on the candidate's language by the technical nature of the medium itself. Media coverage would therefore be this inscription, and that is what concerns us in this work.

The constitution of our corpus implies, of course, a selection from all the programmes broadcast during the period before the publication of the list of candidates by the Constitutional Council, the period after the publication of this list, and finally the period of the official campaign itself. It should be noted that each moment was a highlight throughout this long period covering the election campaign in the broad sense, and was characterized by a set of specific political activities for candidates, their supporters and their political party. In a synchronic perspective, we chose the period covering the official electoral campaign, i.e. the period from 22 September to 06 October 2018, i.e. 15 days. The chosen corpus 
therefore consists of fifteen editions recorded during the fifteen days, for a total duration of 13 hours 8 minutes. We have chosen to focus on a collection of programmes rather than isolated programmes to identify patterns.

\section{Findings}

We first carried out a quantitative analysis, coverage of the media space which is reflected in the determination of the airtime of each party and their candidate, as well as the figures and functions of the policies staged by the political parties and their candidate, some of whose results are presented here, and then comparative qualitative work on the discursive strategies of the audio-visual forms of the different parties and their candidate.

\subsection{Quantitative Analysis}

\subsubsection{Order of Appearance in the Programme and Air Time Allocated}

Table 1 below presents the order of appearance in the programme and the air time allocated to the candidates in the context of this programme, as predefined by Decree No. 021/MINCOM of 21 September 2018.

From the 15-day analysis of the broadcast of the candidates' election campaign programme for the 2018 presidential election, we can indeed "compare" the way in which the various candidates tried to publicize their speech under the same conditions.

\section{Observations}

1) Somewhat paradoxical attitude of some candidates who did not make maximum use of the spaces devoted to the official audio-visual campaign, which could enable them to highlight their messages and gather the widest audience. During the period studied, a quantitative description indicates that, over the total duration of the broadcasts, i.e. $13 \mathrm{~h} 08 \mathrm{mn}$, the airtime is as follows:

CPDM: 1h49mn19s; UNIVERS: 1h39mn55s; CRM: 1h38mn30s; SDF: 1h32mn20s; PURS: 1h32mn06s; UDC: 1h24mn03s; MCNC: 1h14mn04s; PFD: 1h02mn35s; ADD: 52mn03s.

Thus, the airtime of the various candidates varies significantly according to the number of times they participate in the programme. Each candidate therefore had fifteen sequences of an average format of $6 \mathrm{mn} 40 \mathrm{~s}$ each. Of the 15 days of issues, the UDC and PFD recorded 05 days of absence; PURS 02 days and SDF 01 day of absence. Given the decisive role that audio-visual media can play in an electoral process, these media, which remain the main source of information for citizens on the various programmes of the electoral campaign, thus helping to enlighten them on the stakes of the election. Indeed, we can wonder about the real motivations of some candidates to win the support of voters in this presidential election if they do not take into account the informational dimension, by making themselves known and making known their vision of Cameroon. Some scores such as ADD (52mn03s) and PFD (1h02mn35s) raise questions. This difficulty in making judicious and relevant use of the promotional and informational space devoted to this effect simply indicates that the parties are unprepared. 
Table 1. Order of appearance in the programme and air time allocated to the candidates.

\begin{tabular}{|c|c|c|c|c|}
\hline $\begin{array}{l}\text { Running } \\
\text { order }\end{array}$ & $\begin{array}{l}\text { Candidate (name, party or movement, political } \\
\text { function(s) during the campaign }\end{array}$ & $\begin{array}{l}\text { Campaign, slogan, } \\
\text { voting instructions }\end{array}$ & $\begin{array}{l}\text { TV airtime } \\
\text { per day }\end{array}$ & Details \\
\hline 1 & $\begin{array}{l}\text { Paul BIYA (85 years) } \\
\text { Cameroon's People Democratic Movement (CPDM) } \\
\text { President of the CPDM (since 1985) } \\
\text { President of the Republic (since 1982) }\end{array}$ & $\begin{array}{l}\text { Paul BIYA, The Force of } \\
\text { Experience. }\end{array}$ & $6 \mathrm{mn} 40 \mathrm{~s}$ & $\begin{array}{l}\text { President of the Republic since } 1982 \text {, he } \\
\text { has already been the candidate since } 1984 \text {, } \\
\text { and has been re-elected } 7 \text { times. }\end{array}$ \\
\hline 2 & $\begin{array}{l}\text { GARGA HAMAN Adji ( } 74 \text { years). } \\
\text { Alliance for Democracy and Development (ADD). } \\
\text { President of the ADD (since } 4 \text { June 1991). } \\
\text { Former Minister of Public Service and Supreme } \\
\text { State Control. }\end{array}$ & The right man for the job & $6 \mathrm{mn} 40 \mathrm{~s}$ & $\begin{array}{l}\text { He ran for the presidency of the Republic } \\
\text { for the first time in } 2004 \text { and then in } 2011 . \\
\text { He has never held an elected office. }\end{array}$ \\
\hline 3 & $\begin{array}{l}\text { KAMTO Maurice ( } 64 \text { years) } \\
\text { Cameroon Renaissance Movement (CRM) } \\
\text { President of the CRM (since } 22 \text { June 2012). }\end{array}$ & Together it is possible & $6 \mathrm{mn} 40 \mathrm{~s}$ & $\begin{array}{l}\text { He has the particularity of never having } \\
\text { been a candidate in an election before. } \\
\text { Former Minister Delegate to the Minister } \\
\text { of Justice in 2004. Resigns in } 2011 \text {. }\end{array}$ \\
\hline 4 & $\begin{array}{l}\text { LIBII LI NGUE NGUE Cabral ( } 38 \text { years). } \\
\text { National Union for Integration towards Solidarity } \\
\text { (UNIVERS) } \\
\text { Promoter of the " } 11 \text { million citizens" campaign }\end{array}$ & $\begin{array}{l}\text { Cameroon which } \\
\text { protects and releases } \\
\text { energies }\end{array}$ & $6 \mathrm{mn} 40 \mathrm{~s}$ & $\begin{array}{l}\text { He has the particularity of never having } \\
\text { been a candidate in an election before. He } \\
\text { is invested by the UNIVERS party whose } \\
\text { president is Professor NKOU MVONDO } \\
\text { Prosper. }\end{array}$ \\
\hline 5 & $\begin{array}{l}\text { MATOMBA Serge Espoir ( } 39 \text { years). } \\
\text { People united for social renewal (PURS). } \\
\text { First Secretary of the PURS (since 2010). } \\
\text { Douala Municipal Councilor 4th }\end{array}$ & $\begin{array}{l}\text { The fate of Cameroon is } \\
\text { in our hands }\end{array}$ & $6 \mathrm{mn} 40 \mathrm{~s}$ & $\begin{array}{l}\text { He has the particularity of never having } \\
\text { been a candidate in an election before. }\end{array}$ \\
\hline 6 & $\begin{array}{l}\text { MUNA AKERE Tabeng ( } 66 \text { years) } \\
\text { Popular Front for Development (PFD). } \\
\text { Leader of the NOW Movement }\end{array}$ & $\begin{array}{l}\text { Together, let's build a } \\
\text { new Republic }\end{array}$ & $6 \mathrm{mn} 40 \mathrm{~s}$ & $\begin{array}{l}\text { He has the particularity of never having } \\
\text { been a candidate in an election before. He } \\
\text { was invested on June 23, } 2018 \text { by the PFD } \\
\text { whose national coordinator is Mr. Doukou } \\
\text { Daman. He decided to withdraw his } \\
\text { application in favour of Maurice KAMTO. }\end{array}$ \\
\hline 7 & $\begin{array}{l}\text { NDAM NJOYA Adamou ( } 76 \text { years) } \\
\text { Democratic Union of Cameroon (UDC). } \\
\text { President of the UDC (since } 26 \text { April 1991). } \\
\text { Minister of National Education (in 1977). } \\
\text { Mayor of Foumban }\end{array}$ & $\begin{array}{l}\text { Cameroon is through all } \\
\text { of us and for all of us }\end{array}$ & $6 \mathrm{mn} 40 \mathrm{~s}$ & $\begin{array}{l}\text { He ran for the Supreme Court in 1992, } \\
2004 \text {, and } 2011 .\end{array}$ \\
\hline 8 & $\begin{array}{l}\text { NDIFOR AFANWI Franklin ( } 38 \text { years) } \\
\text { National Citizens' Movement of Cameroon (MCNC). } \\
\text { President of the MCNC (since May 2018). }\end{array}$ & $\begin{array}{l}\text { Voting the truth for } \\
\text { change in Cameroon }\end{array}$ & $6 \mathrm{mn} 40 \mathrm{~s}$ & $\begin{array}{l}\text { He has the particularity of never having } \\
\text { been a candidate in an election before. }\end{array}$ \\
\hline 9 & $\begin{array}{l}\text { OSIH Joshua NANBANGI ( } 50 \text { years). } \\
\text { Social Democratic Front (SDF). } \\
\text { Vice President of the SDF. } \\
\text { SDF Parliamentarian in the National Assembly. }\end{array}$ & For a better Cameroon & $6 \mathrm{mn} 40 \mathrm{~s}$ & $\begin{array}{l}\text { He was invested by the SDF on February } \\
24,2018 .\end{array}$ \\
\hline
\end{tabular}

Source: Author's field work.

It should also be noted that at the same time, some parties have favoured reruns, while others such as the CPDM, the CRM or the UNIVERS have systematically chosen to record new programmes.

2) Another surprising result is that, there was no recording of a candidate's intervention in the studio. None of the nine candidates really relied on the media 
made available to them, namely CRTV. It is surprising to note the lack of interest aroused by this stage space devoted to the promotion of candidates. All used this space to broadcast some excerpts from campaign meetings. However, these privileged moments, which benefit from a high level of coverage, impact and audience, constitute a unique opportunity to establish direct contact with voters; they are an opportunity to stand out and earn points from voters. Sometimes, these opportunities to look each other in the eye influence the electorate at the time of the vote. Everyone has a memory in mind of an excerpt from a candidate's speech in an election that was decisive in the results obtained. It is therefore up to the candidate to take advantage of this media space to highlight his programme but also his personality.

\subsubsection{Political Speeches in the Electoral Campaign Broadcast}

In 15 days, we have rather seen a succession on the screen of a variety of personalities who spoke on behalf of their political party and their candidate. Therefore the researcher sought to find out: Who spoke for who? What is the status and understanding of these delegation of speeches? These are some of the questions that guided our approach.

Four types of speeches were distinguished according to the type of political actor on stage. These types of speeches can be distinguished by categorizing their sources. After systematically identifying all the speakers, candidates for election, and their supporters or representatives, we grouped them according to a typology of speech for each political party as presented in Table 2 below.

Table 2. The political voice in the electoral campaign broadcast.

\begin{tabular}{|c|c|c|c|c|c|}
\hline \multirow{2}{*}{$\begin{array}{l}\text { Political } \\
\text { Speeches }\end{array}$} & \multicolumn{2}{|c|}{ Candidate's Speech } & \multirow[b]{2}{*}{$\begin{array}{l}\text { Speech of the } \\
\text { Institutional } \\
\text { of political } \\
\text { party }\end{array}$} & \multirow[b]{2}{*}{$\begin{array}{l}\text { Speech of the } \\
\text { Executive } \\
\text { Member of } \\
\text { Political } \\
\text { Parties }\end{array}$} & \multirow[b]{2}{*}{$\begin{array}{c}\text { The Speeches of } \\
\text { Allied Political } \\
\text { Parties }\end{array}$} \\
\hline & $\begin{array}{l}\text { Studio } \\
\text { recording of } \\
\text { the candidate's } \\
\text { intervention }\end{array}$ & $\begin{array}{l}\text { External video } \\
\text { elements of } \\
\text { the candidate }\end{array}$ & & & \\
\hline UNIVERS & 0 & 3 & 4 & 10 & 1 (UPC) \\
\hline PURS & 0 & 0 & 1 & 17 & \\
\hline SDF & 0 & 0 & 0 & 12 & \\
\hline CPDM & 0 & 4 & 9 & 6 & $\begin{array}{c}1 \text { (PAL), } 1 \text { (UNDP), } \\
1 \text { (UPC), } 1 \text { (UPC), } \\
1 \text { (FSNC), } 1 \text { (UDP), } \\
1 \text { (PADDEC) }\end{array}$ \\
\hline CRM & 0 & 5 & 5 & 15 & \\
\hline PFD & 0 & 0 & 2 & 5 & 2 (USDP), 1 (AFP) \\
\hline $\mathrm{MCNC}$ & 0 & 0 & 1 & 10 & 1 (USP), 1 (BRIC) \\
\hline $\mathrm{ADD}$ & 0 & 0 & 0 & 10 & \\
\hline UDC & 0 & 0 & 8 & 5 & \\
\hline
\end{tabular}

Source: Author's field work. 
From Table 2, we can distinguish between:

- The speeches of the candidate for election himself by means of a report or meeting reports.

- The speeches of representative of political parties: it came from politicians and opinion leaders. These include, leaders and managers of political parties, parliamentarians, senators and members of Government.

- The word of executive members of political parties: it came from top representative, resources persons, and militants of political parties. Examples include the communication coordinator, regional coordinator, divisional secretary, special advisor, section president, etc.

- The speeches of allied political parties: it includes the positions taken by allied parties that have chosen to support a candidate, such as the UPC, USPD, FSNC, BRIC, PAL, etc.

Furthermore, when examined according to this criterion of speech delegation, the contrast between the various types of speeches is obvious. First, the weight of each of the words varies greatly from one party to another. The CPDM calls first on the word of the institutional (09), the word of the allies (07), and the word of the executives (06). Meanwhile, for the CRM, the word of the executives (15) finds a place of choice in its speeches. On the other hand, the candidate's speech is almost ignored by all parties, except the CRM (5), the CPDM (4) and the UNIVERS (3) whose candidates are present on the screen through reports of meetings.

\subsection{Qualitative Analysis}

Let us now turn to the discursive strategies adopted. This study made a comparative analysis within the given discursive universe, which is that of the presidential election campaign programme of candidates for the 2018 presidential election, broadcast from September 22 to October 06 on the national public service television (CRTV). The analysis was done in three levels that form the audio-visual language: the media strategy itself, the thematics treated, and the rhetoric, as indicated at the beginning of this study. It was a question of identifying for each level, the constituent elements of the various discursive strategies.

\subsubsection{The Technical and Communicational Dispositions}

This is understood as a network of heterogeneous elements constituting a set at a given historical moment and responding to a dominant strategic function. This mechanism can be an inclusion of a network of heterogeneous elements in a strategic approach, that of ensuring maximum efficiency or operability in television action (Foucault, 1980).

As in any presidential election, everywhere, each candidate presents himself/herself on the public audio-visual media where he/she benefits from a certain number of programmes of a fixed duration. The candidate is not entirely free to organise his programme as he wishes, insofar as the media itself determines a production strategy which should normally be fair to all candidates. On 
a formal level, a number of grammatical rules of the image were predefined and mandatory for each candidate. Each political party therefore try to publicise and promote its candidate in both substance and form.

\section{1) CRTV's media strategy}

Let us first examine how an institution, CRTV, a public service media, itself organised the media coverage of the election campaign programme. In the continuation of Jérôme Bourdon, we consider here as an institution, as explain by Esquenazi (1995: p. 204), it is a norm of discourse that has crystallized into a material mechanism: the institution is located in space and time, is characterized by a set of techniques and acts that are specific to it'. This is what we call CRTV's media strategy or system. It should first be noted that the Ministry of Communication, the Ministry responsible for the management of CRTV, sets the rules concerning the conditions for the production, programming and broadcasting of programmes relating to the 2018 Presidential election campaign. These rules propose a method of producing programmes by recording in the studio in the structure hosting the post-production. The broadcast itself consists of a succession of spots or large format modules. Each candidate has an equal duration of 6 '40s spot. As there were nine candidates, the total duration of the spots during a broadcast is 60 minutes, except for the opening and closing credits of the broadcast, as well as the opening credits of the spots. From a descriptive point of view, the election campaign programme over the CRTV was constituted of five elements:

a) Opening credits of the issue

b) Opening credits for each spot

c) Spot of each candidate or their supporters

d) End credits for each spot

e) End credits of the issue

The credits at the beginning and end of the broadcast feature an animation of the Unity Palace, which is the main focus of this campaign; it is expected to welcome the next President of the Republic. An inscription, "2018 Presidential" is superimposed. Then follow nine panels on which are written the names of the various candidates who are scrolling one after the other. The credits end with the title of the programme: "Presidential election of 07 October 2018-Space reserved for the candidates' electoral campaign". In addition, each candidate spot is preceded by a credit, the same as the one of the programme but with different texts, here we indicate the name of the candidate, his political party, and the subject of the programme: "2018 Presidential Election", in French and English. The function of this spot generic is twofold: first, it serves as a punctuation, it marks the transition from one spot to another, it is first of all the opening of a specific scenic space; and it also functions as an identification marker insofar as it indicates the name of the candidate and his political party.

The scenic mechanism of each spot is built around a static close-up plane, whose outer limits form the stage. The stage is in every way comparable to the stage of the theatre: a circumscribed space, enclosed in a set, open only to the eye of the camera, the only audience to which presenters and actors address them- 
selves. The studio set imposes its spatial and territorial realities here. It imposes a number of scenographic elements, accessories, and decoration. It should be noted that the scenic space proposed in this programme is sober and consists of a plain grey background, with a white envelope on the left side to collect a ballot paper, the flag of Cameroon and a geographical representation of the national territory; all framed by two texts: “Élection présidentielle 2018” et "2018 Presidential election". A global conception of space: focus on a single point in order to focus on current performance. The stage space occupied by the subjects is a stage space that aims to eliminate anything that can distract the viewer's gaze; it privileges the speech of the speakers while taking care to avoid any sign or clue that may belong to a political party. Neutrality is required. The set here is filmed as a single camera, only one type of shot forms the frame of the staging: a camera is placed in front of the speaker to capture it in a close-up shot from the beginning to the end of the action, and in the same camera axis or frontal and horizontal viewpoint. The image is therefore extremely immobile, no change of plane can be made in the framing. This elementary staging allows viewers to focus all their attention on the subject. The choice from a horizontal and frontal point of view implicitly or by convention induces, from the psychological point of view, the neutrality, objectivity and involvement of the television viewers. A connection, through the look "eyes in eyes". We thus find ourselves in a situation where a man or a woman, placed in front of the camera, looks at it directly and thus addresses the viewer without intermediary, "eyes in the eyes" (Veron, 1985). It is this direct gaze of the actress towards the viewer that makes the power and specificity of the television medium; as a general rule, it is a question of questioning or of creating a direct contact, a complicity. At the same time, the close-up framing reinforces the impression of proximity to which, moreover, the discourse also contributes with questions such as: "Beware of this system...", "Don't forget to put this ballot in the box...". The media system, as organised by CRTV, was designed to highlight the candidates' messages and to attract the widest possible audience and attention. Equity and then equality were the two structuring principles of the media coverage of the Presidential election. These two principles gave the different parties and/or candidates the opportunity to deliver their message and to benefit from equal speaking time and treatment.

\section{2) The media strategy of the candidates or political party}

This system inherent in the candidate's language game, which would be the discursive space from which the speech proceeds, must first of all show how the candidate and his party speak to the type of public affected by the speech. Then, how it magnifies it and endows it with a number of symbolic values that are visible and materialized in the discourse. It should be recalled here that the candidate seeks to establish and maintain a link with the voter through this discursive space. Here, we will focus on the three main candidates who obtained the highest scores in the 2018 Presidential election. Taking Paul Biya (71.28\%), Maurice KAMTO (14.23\%), Cabral LIBII (6.28\%) as the subject of the study, these three candidates also obtained the highest scores in terms of media coverage. 
The CPDM's interventions during the 15 days of the electoral campaign all start in the same way: the sequence always begins and ends with the official campaign spot of candidate Paul BIYA. The spot, in French and English, evokes and illustrates the themes of national unity, democracy, peace, prosperity and international influence with an ending formula that summarizes the message: "Paul BIYA the Force of Experience". A variability of content furnished the sequences during the 15 days; these were speeches by CPDM politicians or some supporters and sympathizers of the candidate Paul BIYA from various backgrounds, and the broadcasting of extracts from speeches on the occasion of his first campaign meeting in Maroua.

First of all, it should be recalled that each candidate made use, in his own way, of the television technique and media system as organized by CRTV, i.e. he or she made it a technology suitable for receiving his speech.

Let's first look at how Paul BIYA and the CPDM are facing the challenge. In general, the strategy set up by CRTV was based on live diffusion technology, eventhough if the programme itself is broadcast on a deferred basis. Each participant is captured in live conditions with a camera that films continuously and in a single camera axis, no change of shot or "cut" is planned. It should be noted that the CPDM amplifies this choice of live technology by broadcasting several excerpts from the presidential candidate's campaign speeches at its first meeting held in Maroua in the Far North. We are in a situation where the production of the meeting was really done under live conditions, but there is a willingness on the part of the CPDM to make the production of these images coincide with their reception. In these excerpts, we can note close or wide fixed shots of the President-Candidate delivering his speech; Sometimes, some changes of shots occur to alternate speeches of the President-Candidate, personalities present at the ceremony and public reactions, but the technology used is indeed that of live television. How to understand this bias? Therefore, how to understand the type of mediation desired by the CPDM.

We said that the programmes broadcast by the CPDM offer the viewer during these 15 days of campaign a recognizable situation. This involves a technology that uses a direct effect. The notion of live television is unambiguous; two temporal features define live television: chronology and simultaneity. While the first concerns events, the second characterizes the viewer's relationship to the event. Live defines a simultaneous relationship between the moment the programme takes place and the viewer's time.

The CPDM campaign broadcasts are a live image broadcast, but their production and broadcasting have previously taken place. Even if these sequences of images obey the chronology of the event, they do not coincide with their reception. Is it possible, particularly by respecting the continuity of an event, to give the impression of this coincidence when it does not exist. Indeed, as shown by several TV programmes, most of which are recorded under live conditions but which are only broadcast long after that. Moreover, it is quite possible that several viewers watched these images when they were broadcast live from Maroua 
to realize that they were in fact rebroadcasts of meeting extracts as part of campaign programmes. But the viewer very often accepts this state of affairs because what he knows about the technique allows him to accept it. To understand the type of mediation desired by the CPDM, live technology must be viewed as a mechanism for immediate contact and a promise of authenticity between a candidate and his electorate. The audio-visual mediation operated by the technique when it alternates the plan of the President-Candidate giving his speech, the look at the camera and the audience, puts them, in short, in the situation of a conversation in which the viewer would be the silent interlocutor (Jost, 1990).

In addition to the live technology, and therefore the presentation and search for authenticity, implemented by the CPDM, the latter makes other strategic choices. We asked ourselves what kinds of speeches were used. We assume that the speakers' words are not simply a series of juxtaposed statements, the words are necessarily organized around structured forms that allow us to say what we have to say. Based on a meaningful organization of various materials (linguistic, sound, iconic), the media construct a discursive staging of phenomena that are the daily life of information according to the modes of discursive, narrative, descriptive, argumentative organization (Jamet \& Jannet, 1999). Therefore, any text or speech can be considered as a series of sequences organized for a coherent overall goal and the search for an effect.

From this observation, we were able to identify five types of prototype sequences characterizing the primary genres of discourse: the narrative sequence, the descriptive sequence, the argumentative sequence, the explanatory sequence, the dialogical sequence (Adam, 1992). From the analysis of the linguistic, sound and iconic material of the fifteen CPDM programmes throughout the campaign, they all use the argumentative method. This choice of argumentative method by most candidates is understandable given the electoral context. Ultimately, argumentation is first and foremost what convinces the viewer that what is said or shown is a truth about the real world. It is true that the image is quite unfit to make the argument, it is more capable of showing, and it is remarkable for amplifying the oratory qualities, i.e. the emotional aspects. To support our point, we can note in the interventions of political parties, a strong tendency to argumentation which translates into an inflation of the word, to systematically want to propose knowledge on a question, a problem or on the actions carried out; most of the time, too, the choice to use credible speakers, other than the candidate himself, and who inspire confidence. As Charaudeau (1997) explains, trust is linked to the enunciator (the being of speech, i.e. being staged by his or her speech. The most commonly used clues of persons or enunciation in the sequences analyzed highlight the use of the "I"; by this use, the CPDM candidate affirms his place as an enunciator in his statement. In this scenario, well-known personalities will take the floor in turn, including some of the CPDM's top political leaders, such as: Jean KUETE, Secretary General; Jacques FAME NDONGO, Secretary of Communication; Pierre MOUKOKO MBONJO, Deputy Secretary of Communication; 
the Honourable Mary BOYA MEBOKA, CPDM Ndian. Other personalities or supporters of the candidate Paul BIYA such as: The Honourable Robert BAPOOH LIPOT, Secretary General of the UPC; ISSA TCHIROMA BAKARI, National President of the FSNC; Célestin BEDZIGUI, National President of the PAL; BELLO BOUBA MAIGARI, National President of the UNDP... It should nevertheless be noted that at no time did the CPDM candidate, like the other candidates, address voters directly through this media space. It is interesting to note that it is rare for a candidate in an election and a few days before the election not to appear in such a space in order to exploit and benefit from the emotional effects which, it seems, very often evoke reactions of support and sympathy. Yet elsewhere, spaces like these have an extraordinary impact and are a privileged means of establishing direct contact with voters. The CPDM candidate is present in this space four times through excerpts from his speech given at the campaign meeting in Maroua on 29 September 2018. All these extracts reveal a presidential candidate. The circumstances of this meeting are very close to the usual official and public outings of the Head of State on the occasion of official ceremonies. We can see in these images a number of symbols belonging to the President of the Republic: candidate Paul BIYA made Maroua's trip on board the presidential plane, the security and protocol arrangements are in place, the aide de camp is present. Of course, all this could be linked to a strategic and communicative choice of the candidate. So, it could be a posture that the candidate staged in resonance with the political signature of his campaign: Paul BIYA, the candidate of experience.

Finally, it should be noted that throughout the official campaign, the CPDM candidate's media coverage also included other discursive products, which are coordinated actions, organized as part of the candidate's strategy, aimed at achieving concrete objectives in a specific period of time. Tools and gadgets were used to promote the candidate's image. Among these objects, we can mention: the campaign loincloth, tee-shirt, cap, watch, umbrella, creation of an original music, advertising poster, TV spot, therefore a real implementation of political marketing in our political context, which leads us to believe that the campaign mechanism of candidate Paul BIYA is a mechanism that could reflect a prestigious image of a politician who wants to be modern, like the solemn declaration of his candidacy through social networks.

Maurice KAMTO's choice also implies a willingness to use the face-to-face and therefore also recourse to direct effects, essentially in the form of dialogue between himself and the audience during his meetings; he addresses it by means of the football metaphor. For the CRM candidate: "we have to score the penalty"; he holds a football and is dressed in the Indomitable Lions jersey; he successively sets out the proposals of his programme, thus fostering communion with his audience.

Let us first examine how the candidate structures his media discourse space. Of the fifteen programmes, candidate Maurice KAMTO appears five times com- 
pared to four times for the CPDM candidate. It should be noted, however, that these interventions are not direct, they are extracts from meetings that certainly reproduce the conditions of direct. Generally speaking, the CRM's election campaign broadcasts are always structured in the same way. The programmes open and close with the CRM candidate's official campaign spot, which shows a variability of images including those of the candidate himself, a map of Cameroon, the candidate's ballots, and folk dances from our cultural space. Here too, the programmes are hosted by one of Maurice KAMTO's followers, Sosthène Médard LIPOT, advisor to the National President, who is also a journalist by training. Indeed, the latter, making use of his professional skills, will use as an audio-visual form the news magazine which mainly focuses on reporting and interviewing. Several interviewees should be noted, such as Éric NJANKWA NJABON, National Secretary of Communication; Serge YEMGA, leader of the Youth Engaged; Steve BABARI, militant Yaoundé 4; André Blaise ESSAMA and Pierre Marie BEBGA, supporters of the CRM candidate.

If we must summarize the way in which the CRM candidate has made use, in his own way, of television technology, that is, that he has made it a technology suitable for receiving his speech, we can essentially retain two types of technicality:

First, the broadcasting of long extracts from meetings held in Ebolowa, Dschang, Yaoundé, and Douala. Indeed, this form, which denies any power of intervention or manipulation in the filmed continuity, actually covers the form of the live, as if the live left the discourse in its original purity by favouring rather a direct contact with the audience. In addition, the other type of technicality used by the CRM candidate in his programmes is reporting and interviewing. Unlike live reporting, reporting is perceived as another type of discourse; it is seen as an interpretation of a proven reality. So it gives itself as a serious genre (Searle, 1983) that is, it mobilizes an interpretation that attributes the discourse to a I-a real origin (Odin, 1984). The candidate Maurice KAMTO, by choosing the technology of reporting, thus poses as an interpreter of a proven reality.

Cabral LIBII's interventions usually begin with a short video production, of 31 seconds with 25 shots. In most cases, UNIVERS' campaign broadcasts also end with a short sequence on the candidate's campaign tours in several regions of Cameroon. It should be noted that for the short video production, continuity is ensured by a musical rhythm with traditional sounds on which images on scenes of daily life and folk dances are superimposed, interspersed with speeches by citizens, in French and English, to present the candidate's strengths and outline some important themes of the campaign. On the other hand, the short sequences of the campaign tours of the UNIVERS candidate are essentially accumulations of images of the public coming to attend the various campaign meetings in the cities of Edéa, Douala, Kribi and Mbouda, to indicate the density, enthusiasm and joy of the crowd. It can also be observed that the candidate uses several national emblems: the national anthem is always sung at the beginning of each 
meeting, and there is also an important presence of the national flag. It is interesting to note that the logos of the two parties, UNIVERS and 11 Million citizens, appear on both sides of the TV screen and constitute the signature of this announcement. It should perhaps be recalled here that Cabral LIBII is the only candidate who has been invested under the banner of another party, the UNIVERS party. This decision to display the two logos is a desire for these two political parties to materialize the political coalition that exists between the two entities.

The media system here is easily recognizable, it is that of reporting. When the UNIVERS candidate begins his media sequence with a report consisting of portraits and sentences, male and female voices, it is to show the reality of the effects produced by the CPDM's governance on Cameroonians. It is therefore the relationship between Cameroonians and the programme of the UNIVERS candidate that is staged in the sequence. We seem to be talking about a factual reality here. Cabral LIBII therefore poses as a commentator, or rather as an interpreter enlightened by a reality through reporting.

At the end of the reading and analysis on the media strategies of the candidates for the 2018 presidential election, we saw that each candidate made use, in his own way, according to his posture, of a television technicality. Reporting seems to be a form of mediation intended by opposition candidates; the CPDM candidate opts for the search for the direct effect. As we can see, a media strategy is always associated with a discursive form.

\subsubsection{The Thematics Treated by Candidates and Their Political Party}

From the analysis of the 15-day broadcast of the election campaign of candidates for the election of the President of the Republic, which took place from Saturday 22 September to Saturday 06 October 2018, we cannot expect an absolute quantitative description; the place given to any one theme, for example, is certainly not representative of a full year including the campaign period prior to the one opened by the Constitutional Council's establishment of the list of candidates, including the one opened after this publication, and during which candidates already enjoy the same benefits from the State's public services.

Indeed, elections are generally an opportunity to raise issues of interest to citizens, women and men. Among the most recurrent problems are unemployment, security, education, sport and much more. Political parties present their solutions to the major problems on which the electorate must decide, and for which it gives them a mandate. Each of the candidates in the 2018 presidential election has developed a concrete political offer, we are referring here to the political programme, which is reflected in the 15 broadcasts constituting the official electoral campaign on CRTV. We know that an election is sometimes won on themes; and the most striking example we still have in mind is that of former American President George Bush Jr. Indeed, the latter owes much of his 2004 re-election to the theme of security following the 2001 attacks. After these attacks, he positioned himself as the security candidate because the security issue took centre stage in the media. 
Another equally obvious example is that of the National Front in France with Jean Marie Le Pen or Marine Le Pen, who built an entire political party on an ideology based on the theme of immigration. Studying the content of the audio-visual messages to CRTV of the candidates for the 2018 presidential election therefore appears to be a way of knowing the content of what citizens were receiving from the programmes, and therefore, to reveal the programmes and visions of the future.

We first carried out a quantitative analysis (types of subjects, number of occurrences), some results of which are presented here, then a comparative qualitative work on the themes and sub-themes developed by the different political parties. Here, we will focus on the three best candidates.

After reading and analysing the contents of the 15 programmes, a number of themes emerged for each candidate that could influence the outcome of the election. In general, these themes are shaped by the economic and social situation of the country, but also by the personality of the candidate and the presumed expectations of the electorate. A brief review of the themes that led to the election for each of the candidates and a highlighting of some of them in Table 3.

Paul BIYA clearly draws on his experience as Head of State since 1982, recalling the establishment of democracy, peace, national unity, prosperity and international influence. Through the slogan that deeply inspires the CPDM candidate's programme: "Paul BIYA the Force of Experience", we can even see that he reminds Cameroonians of the major role he played for Cameroon in the context of great ambitions or opportunities. This reference to the past is also highlighted in the support of BEDZIGUI Célestin, national president of the PAL; EKINDI Jean-Jacques, coordinator of the MP; MOMO Jean de Dieu, president of the PADDEC; Bello Bouba MAIGARI, national president of the UNDP.

\section{1) Candidate Paul BIYA}

The thematics that made up the campaign of candidate Paul BIYA is presented in Table 3 below.

During the period studied, only four thematics emerged with regard to the context and situation of the country, but also to the candidate's own personality. The four main thematics are: social issues; the nation; the economy, development and major opportunities; security, defence and peace.

The presidential candidate Paul BIYA has given more importance to the social and the Republic; the economy and security, just as important, are in second place.

\section{2) Candidate Maurice KAMTO}

For Maurice KAMTO, the CRM candidate, the main argument throughout the campaign was change: the Cameroonian dream, which monopolized the campaign speech. It is this same argument that can be found in all the 15 programmes that make up the CRM's official campaign. This can be read in the slogan on campaign posters: "Together it is possible". The two proposals: "Change, the Cameroonian dream" and "Together it is possible" are consistent and relevant, and are in a cause-and-effect relationship. 
Table 3. The political thematic choice of candidate Paul BIYA.

\begin{tabular}{|c|c|c|c|}
\hline \multicolumn{4}{|c|}{ Paul Biya's vision: The Force of Experience } \\
\hline & Themes & Sub-themes & $\begin{array}{l}\text { Number of } \\
\text { occurrences }\end{array}$ \\
\hline 1 & $\begin{array}{l}\text { Economy/ } \\
\text { Development/ } \\
\text { Major opportunities }\end{array}$ & $\begin{array}{l}\text { Economic recovery, structural projects, digital shift, } \\
\text { infrastructure development, improvement of economic } \\
\text { and social standards, economic diversification, } \\
\text { industrialization, acceleration of growth. }\end{array}$ & 13 \\
\hline 2 & $\begin{array}{l}\text { Security/ } \\
\text { Defence/ } \\
\text { Peace }\end{array}$ & $\begin{array}{l}\text { Fight against Boko Haram and the secessionist movements } \\
\text { in the North-West and South-West regions; restore peace, } \\
\text { security challenges, maintenance of peace and national } \\
\text { unity, stability of Cameroon, security of property and } \\
\text { persons. }\end{array}$ & 10 \\
\hline 3 & The Republic & $\begin{array}{l}\text { National unity, solidarity, dialogue, prosperity, freedom, } \\
\text { democracy, institutional modernisation, territorial } \\
\text { integrity, Good governance, good practices in the } \\
\text { management of public affairs. }\end{array}$ & 15 \\
\hline 4 & Social & $\begin{array}{l}\text { Unemployment, family, sustainable development, health, } \\
\text { progress, education, living together, living conditions } \\
\text { improvement, sustainable development. }\end{array}$ & 16 \\
\hline 5 & Social Justice & Corruption & 1 \\
\hline
\end{tabular}

Source: Author's field work.

In his part, Maurice KAMTO must rely on a campaign vision that is close to his heart and make it his main focus: change. However, as presented in Table 4 below, three thematics seemed particularly important to the CRM candidate. The thematics are: social issues; governance; and the economy.

Table 4 indicates that for the three main political thematics choice of CRM party, social issues and governance occupied a place choice and the economy came in the third and last position.

\section{3) Candidate Cabral LIBII}

The content of Cabral LIBII's speech is also based on the questioning of the policy of the presidential candidate Paul BIYA. For the UNIVERS candidate, it is also the change and the break-up that are highlighted. While his proposals effectively summarize the break-up and change that appears forcefully in all 15 of the party's programmes, his campaign slogan: "Cameroon that protects and releases energies" seems not to be closely related to the discourse, or only anticipates it from a distance.

With regard to the UNIVERS candidate, Cabral LIBII, whose campaign is oriented by a vision of break-up and change, Table 5 below indicates that two main thematics emerged. The thematics are: governance; and social issues.

Table 5 clearly indicates that Governance emerged as the main thematic of the UNIVERS candidate, and to some extent social issues. It should be noted that for the candidate of the UNIVERS, it is also the youth that is put forward. In his statement of faith, he insists on the desire to establish a new political force. This one clearly reads in its slogan: "Cameroon which protects and releases the energies" that is opposed to "The Force of Experience" of the CPDM candidate. 
Table 4. The political thematic choice of candidate Maurice Kamto.

\begin{tabular}{cccc}
\hline \multicolumn{3}{c}{ Maurice Kamto's vision: change, the cameroonian dream } \\
\hline \multicolumn{2}{c}{ Themes } & \multicolumn{1}{c}{ Sub-themes } & $\begin{array}{c}\text { Number of } \\
\text { occurrences }\end{array}$ \\
\hline 1 & Social & $\begin{array}{l}\text { Work, education, injustice, health, water. } \\
\text { Absence of the President, political and institutional modernisation, } \\
\text { foreign policy, peaceful resolution of the Anglophone crisis. }\end{array}$ & 10 \\
3 & Governance & 9 \\
Modernisation of the economic and productive system, & 7 \\
\hline
\end{tabular}

Source: Author's field work.

Table 5. The political thematic choice of candidate Cabral LIBII.

\begin{tabular}{lllc}
\hline \multicolumn{4}{c}{ Cabral LIBII's vision: Break-up and change } \\
\hline \multirow{2}{*}{ Themes } & \multicolumn{1}{c}{ Sub-themes } & $\begin{array}{c}\text { Number of } \\
\text { occurrences }\end{array}$ \\
\hline 1 & Social & $\begin{array}{l}\text { Health coverage for all, employment for all, girl-mother's } \\
\text { allowance, education. } \\
\text { African and international leadership, sub-regional integration, } \\
\text { sub-regional security issues, academic cooperation, }\end{array}$ & 14 \\
2 & Governance & $\begin{array}{l}\text { strengthening the High Council of the Judiciary, enhancement } \\
\text { of doctors and teachers, corruption, tribalism, women prime } \\
\text { ministers, gender parity. }\end{array}$ & 17 \\
\hline 3 & Economy & Growth economy & 1 \\
\hline
\end{tabular}

Source: Researcher's field work.

The comparative qualitative work informs us about two things: first, the thematic offer of the CPDM has a radically different and broader orientation. On the other hand, the offers of the CRM and the UNIVERS are very close to each other in terms of themes, with a predominance of social issues and governance for these two candidates.

\subsubsection{The Language Style (Rhetoric)}

In any case, the analysis of the main thematic axes leads to figures and allows the implementation of rhetorical processes.

Let us now turn to the discursive strategies adopted. We therefore analysed in detail the texts and images of the 15 programmes, emphasising one of the elements of a discursive strategy, namely the staging of the media discourse. We illustrate the main results here.

Based on each candidate's strategic choice, that of staging his own mediation activity, or even his interventions in the course of the programmes, we can identify two types of mediations that we will call "discreet mediator" for the CPDM candidate and "active mediator" for the CRM and UNIVERS candidates. The discreet mediator is constructed as giving citizens elements that allow them to form their own opinion. It is based on its governance, this reference to the past places it in the demonstration. He puts less emphasis on his mediation work, it is 
his spokespersons who testify and list the achievements, and he does not speak much in his own name.

As for the active mediators Maurice KAMTO and Cabral LIBII, the latter mark their presence in the mediation activity. They inform and interpret the country's situation at all levels in their own name. They inform and interpret the country's situation at all levels in their own name.

As the first signifier of the construction of an active mediator, Maurice KAMTO and Cabral LIBII present the criticism, protest and denunciation of the inadequacies of the ruling party and its leader. It is the mediator himself who interprets and judges:

Maurice KAMTO: "I no longer want a Cameroon where people wait for rainwater, puddles of rainwater on the road to drink water". Or, "I am here to fight against injustice: there is poverty in the South, there is poverty in the South, and I will fight this and it will end" (Programme of 03/10/2018).

As for Cabral LIBII: "There are among the elders, the good and the bad; the bad have the force of experience of theft, the bad have the force of experience of corruption, the bad have the force of experience of condescension and contempt, the bad have the force of experience of misappropriations, the bad have the force of experience of tribalism" (Programme of 06/10/2018).

The rhetoric here only amplifies the usual features of any information and uses all possible figures of traditional rhetoric. The choice of words in the above examples seems to be based on hyperbole, hence the inflation of statements that produce rejection due to the situation.

Thus, dramatization, that is, the willingness to amplify the signs, remains a constancy that underlies the media information of the active mediator. This shows the informants' willingness to put the public in a kind of direct contact with the situations described, which leads to the denunciation of opponents being exposed. We also note in Maurice KAMTO, a rhetorical process based on the comparison with football. This incessant pounding of the penalty shooter, often dressed in Cameroon's national team jersey and holding a football, produces emphatic effects by reproducing a football situation and vocabulary: “...I am ready to shoot the penalty, I am ready to be the third President of the Republic of Cameroon, we are ready to lead the country...".

Another example of the construction of an active mediator, coming from the adoption of political meetings as an essential element of a campaign strategy by CRM and UNIVERS candidates. For both, the majority of the programmes include extensive excerpts from campaign meetings. Indeed, meetings have the particularity of promoting direct contact and interaction with voters. Moreover, candidate Maurice KAMTO presents himself as the one who will have travelled through the ten regions of Cameroon for the electoral campaign.

On the other hand, the discreet mediator takes a certain distance from the facts he describes. An example, the fundamental difference in enunciation strategies, i.e. the intentional part of visual and verbal mediation of the audio-visual content of the campaign: the vision of Cameroon that the presidential candidate 
deploys. When he holds his campaign meeting on 29 September 2018 in Maroua, it is in his dual position as President of the Republic and candidate that he presents himself to his voters. He clearly draws on his experience as Head of State, recalling the many achievements, such as the Wouri Bridge, hydroelectric dam, football stadium, democracy, peace, national unity, national integrity... In the slogan "The force of experience", everything is said; it is necessary to say as little as possible. The most appropriate rhetorical figure for this type of statement is the understatement. Moreover, it is also noted that the discreet mediator almost never denounces, he never gives the names of his opponents, he only exposes and shows rather than demonstrates, in order to let the citizen form his own opinion.

The main thematic axes: for the CPDM candidate, the experience and exposure of the balance sheet of his seven-year term; the dramatization of the balance sheet of the CPDM by the CRM and the UNIVERS, reflect the partisan and ideological discourses of the political parties in the running. It should be noted that these speeches have been diluted into more generalist approaches, aimed at seducing Cameroonians. Due to the similarity and weakness of the political offers of the opposition parties, the speeches of the various candidates suffer from a lack of credibility. No candidate mentioned the possible financing of the measures they propose (Payment of an allowance to all young mothers of a child for candidate Cabral LIBII). Although in politics, form may be preferred over substance, voters may therefore tend to be influenced by the personality of candidates. Did the presidential candidate Paul BIYA foresee this?

\section{Conclusion}

At the end of this article, we discussed the triptych composed of the media mechanism, the theme and rhetoric that form the audio-visual language of the policy speeches for the 2018 Presidential election in Cameroon.

Indeed, the audio-visual language of policy discourse has a specific function, and it is skilfully designed to achieve its objectives. If we can consider, in the end, that with Paul BIYA's election campaign, the CPDM has entered the era of political marketing, the fact remains that for the opposition parties, the campaigns lack construction and relevance.

Of the three elements that make up the audio-visual language of policy discourse, only the theme and to a certain extent the media system received careful treatment by the three candidates. With regard to the theme, it was more a question of magnifying the art of convincing by arguments that shake certainties, by demonstrations, by evidence ... or by reasoning; each candidate used a media technology that suited him, descriptive strategy for the CPDM, reporting for the CRM and the UNIVERS. On the other hand, the emotional dimension was cruelly lacking in this campaign. However, the emotion at the level of content and form, which at first glance creates a reaction of adherence and a sense of importance.

We think we have tried to show that a media technology is always associated with a discursive form. Within an election campaign, there is only media tech- 
nology associated with a language game. Media technology, choice of theme and discursive staging are closely linked and relevant. It is only at this price that they make sense. It is therefore a construction of the candidate.

For example, one of the practical implications that can be drawn is that live technology makes television a tool for immediate contact, closeness and authenticity between a candidate and his or her audience. Politicians generally make use of it. When a politician speaks on television directly to the viewer, it is because he or she is always well aware of the effects on his or her own discourse.

\section{Conflicts of Interest}

The author declares no conflicts of interest regarding the publication of this paper.

\section{References}

Adam, J.-M. (1992). Les Textes: Types et Prototypes. Paris: Nathan Université.

Bourdon, J. (1998). L'archaïsme et la postmoderne, éléments pour l'histoire d'un peu de télévision. In. J. Bourdon, \& F. Jost (Eds.), Penser la télévision, actes du colloque de Cerisy (pp. 15-28). Paris: Armand Colin.

Charaudeau, P. (1997). Le discours dinformation médiatique. La construction du miroir social. Paris: Nathan-INA, Collection Médias-Recherches.

Esquenazi, J.-P. (1995). Le téléspectateur institutionnel. In. J-P. Esquenazi (Ed.), La télévision et ses téléspectateurs (pp. 203-217). Paris: L'Harmattan.

Foucault, M. (1969). L'archéologie du savoir. Paris: Gallimard.

Foucault, M. (1980). Interview à Ornicar. In E. Allemand (Ed.), Pouvoir et télévision: les machines d'organisation (p. 10). Paris: Anthropos.

Jamet, C., \& Jannet, A-M. (1999). Les stratégies d information. Paris: L’Harmattan.

Jost, F. (1990). Un spectateur en quête d' auteur (p. 64). Bruxelles, Hiver: Degrés.

Odin, R. (1984). Film Documentaire, Lecture Documentariste. Saint-Etienne: Travaux XLI Cinémas et réalités.

Searle, J. (1983). Sens et expression. Paris: Minuit.

Veron, E. (1985). Il est là, il me voit. Communication (p. 38). 